EFFECTS OF HEAT TREATMENT ON THE MICROSTRUCTURE AND MECHANICAL PROPERTIES OF URANIUM-6 NIOBIUM ALLOY

W. B. Snyder

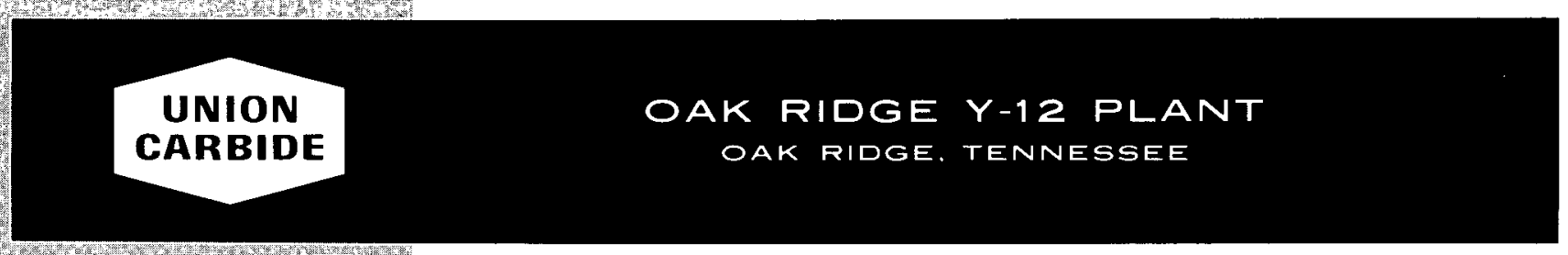

prepared for the U.S. DEPAR TMENT OF ENERGY under U.S. GOVERNMENT Contract W-7405 eng 26 


\section{DISCLAIMER}

This report was prepared as an account of work sponsored by an agency of the United States Government. Neither the United States Government nor any agency Thereof, nor any of their employees, makes any warranty, express or implied, or assumes any legal liability or responsibility for the accuracy, completeness, or usefulness of any information, apparatus, product, or process disclosed, or represents that its use would not infringe privately owned rights. Reference herein to any specific commercial product, process, or service by trade name, trademark, manufacturer, or otherwise does not necessarily constitute or imply its endorsement, recommendation, or favoring by the United States Government or any agency thereof. The views and opinions of authors expressed herein do not necessarily state or reflect those of the United States Government or any agency thereof. 


\section{DISCLAIMER}

Portions of this document may be illegible in electronic image products. Images are produced from the best available original document. 


\section{Printed in the United States of America. Available from National Technical Information Service \\ U.S. Department of Commerce \\ 5285 Port Royal Road, Springfield, Virginia 22161 \\ Price: Printed Copy $\$ 4.50$; Microfiche $\$ 3.00$}

This report was prepared as an account of work sponsored by an agency of the United States Government. Neither the United States Government nor any agency thereof, nor any of their employees, nor any of their contractors, subcontractors, or their employees, makes any warranty, express or implied, nor assumes any legal liability or responsibility for any third party's use or the results of such use of any information, apparatus, product or process disclosed in this report, nor represents that its use by such third party would not infringe privately owned rights. 
Date of Issue: October 13, 1978

Distribution Category: UC-25

\title{
EFFECTS OF HEAT TREATMENT ON THE MICROSTRUCTURE AND MECHANICAL PROPERTIES OF URANIUM-6 NIOBIUM ALLOY
}

\author{
W. B. Snyder \\ Metallurgy Department \\ Y-12 Development Division
}

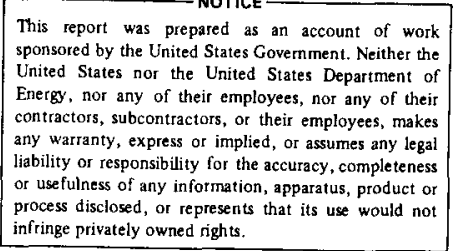

Oak Ridge Y-12 Plant

P. O. Box Y, Oak Ridge, Tennessee 37830

Prepared for the Department of Energy Under US Government Contract W-7405-eng-26 


\begin{abstract}
Aging studies on uranium- 6 weight percent niobium alloy were performed at temperatures of 550 and $600^{\circ} \mathrm{C}$. Mechanical-property measurements and microstructural analyses were used to characterize the aging response of the alloy. An attractive combination of mechanical properties was produced by aging at $550-600^{\circ} \mathrm{C}$; namely, a $0.2 \%$ offset vield strength greater than $730 \mathrm{MPa}$ with an elongation of $15-18 \%$. Increasing the aging time at temperature minimized the variability in mechanical properties. Niobium homogeneity and heating rate influenced the properties and microstructure of the alloy.
\end{abstract}




\section{CONTENTS}

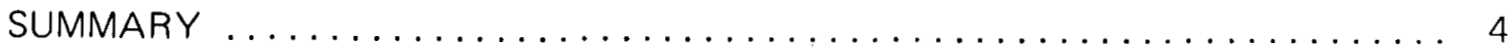

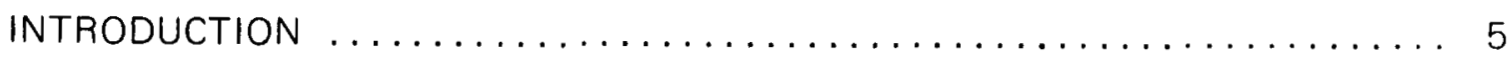

EFFECTS OF HEAT TREATMENT ON THE CHARACTERISTICS OF A URANIUMNIOBIUM ALLOY $\ldots \ldots \ldots \ldots \ldots \ldots \ldots \ldots \ldots \ldots \ldots \ldots \ldots \ldots \ldots \ldots \ldots \ldots \ldots$

Literature Review . . . . . . . . . . . . . . . . . . . . . . . 6

Experimental Procedure . ......................... 7

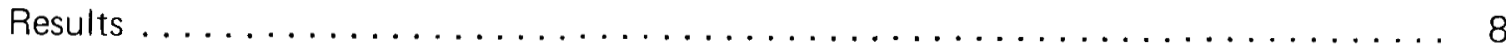

Mechanical Properties ......................... 8

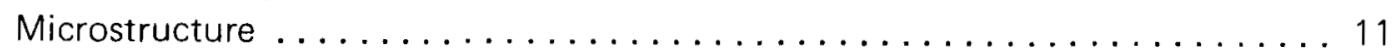

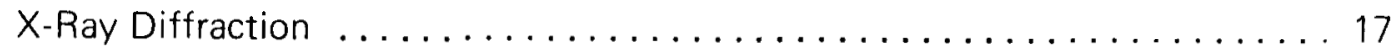

Discussion of Results . . . . . . . . . . . . . . . . . . . . . . 17

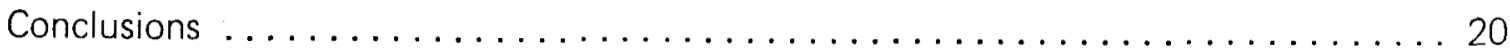

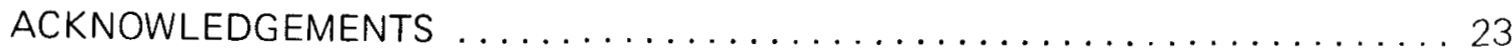

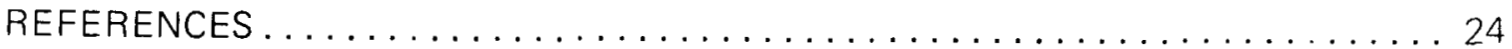




\section{SUMMARY}

A study has been made of the effects of high-temperature aging on the mechanical properties of uranium-6 wt \% niobium (U-6 Nb) alloy. A very useful combination of properties was produced by aging at $550-600^{\circ} \mathrm{C}$; namely a $0.2 \%$ offset yield strength greater than $730 \mathrm{MPa}$ with an elongation of $15-18 \%$. Niobium homogeneity of the starting material and the heating rate during aging influenced the properties of the alloy. 


\section{INTRODUCTION}

Cursory investigations have shown that material with a high yield strength and good ductility can be produced by aging the uranium- 6 wt \% niobium (U-6 Nb) alloy at temperatures above $500^{\circ} \mathrm{C}$. Aged material offers the advantages of high strength with low susceptibility to stress-corrosion cracking; a major disadvantage to the aged material is its poor general corrosion resistance. Nonetheless, the gains in strengthening outweigh the decreased corrosion resistance and warrant further development of the aging treatments. The present study was undertaken at the Oak Ridge Y-12 Plant ${ }^{(a)}$ to characterize the response of U-6 Nb to high-temperature aging treatments. A primary goal of this research was to establish an optimum heat treatment for use in producing a high-strength U-6 Nb alloy.

(a) Operated by the Union Carbide Corporation's Nuclear Division for the Department of Energy. 


\section{EFFECTS OF HEAT TREATMENT ON THE CHARACTERISTICS OF A URANIUM-NIOBIUM ALLOY}

\section{LITERATURE REVIEW}

The uranium-niobium phase diagram is shown in Figure 1, Graph a, while the uranium-rich portion is presented in Graph b. 1 There is considerable disagreement on the exact monotectoid reaction temperature and composition; therefore, Figure 1 represents a best estimate of the phase diagram. If alloys near the 6 weight percent niobium composition are quenched rapidly from the high-temperature bcc gamma $\left(\gamma_{1}\right)$ phase field, a metastable phase of alpha (a) uranium is formed martensitically. Commonly known as alpha double prime $\left(\alpha^{\prime \prime}\right)$, this phase is a monoclinic distortion of the orthorhombic $\alpha$-uranium structure. ${ }^{2}$ The exact monoclinic cell size and angle are dependent upon the niobium content and rate of quenching from the $\gamma_{1}$ region. If the alloy exists as $\alpha^{\prime \prime}$ at room temperature and is up quenched into the temperature range between 400 and $625^{\circ} \mathrm{C}$, the $\alpha^{\prime \prime}$ structure will transform to the equilibrium $\alpha$ and $\gamma_{2}$ phases. If the alloy is down quenched from the $\gamma_{1}$ phase field to between 400 and $625^{\circ} \mathrm{C}$, the $\gamma_{1}$ phase also transforms to $\alpha$ and $\gamma_{2}$. Decomposition of either the $\alpha^{\prime \prime}$ or $\gamma_{1}$ phase in this temperature range results in a lamellar or pearlitic microstructure. Jackson 3,4 has reported that a 13 at \% (5.5 wt \%) niobium alloy decomposed, by a gradual change in the $\gamma$ composition (and lattice parameter), to

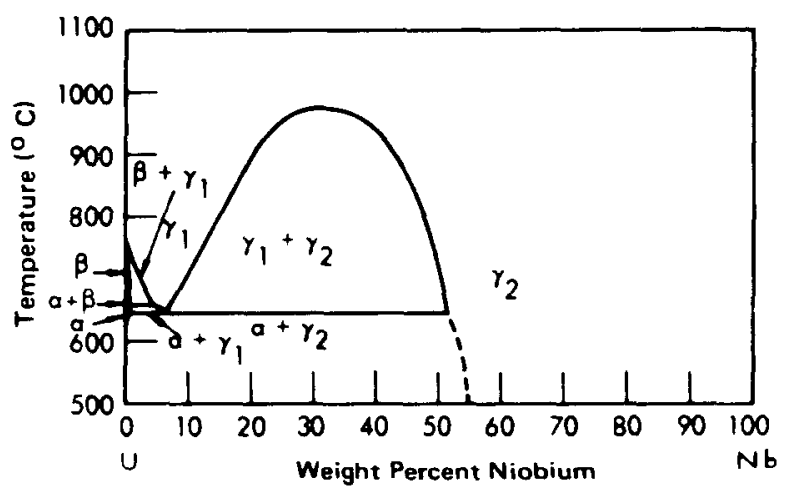

(a) Overall Diagram.

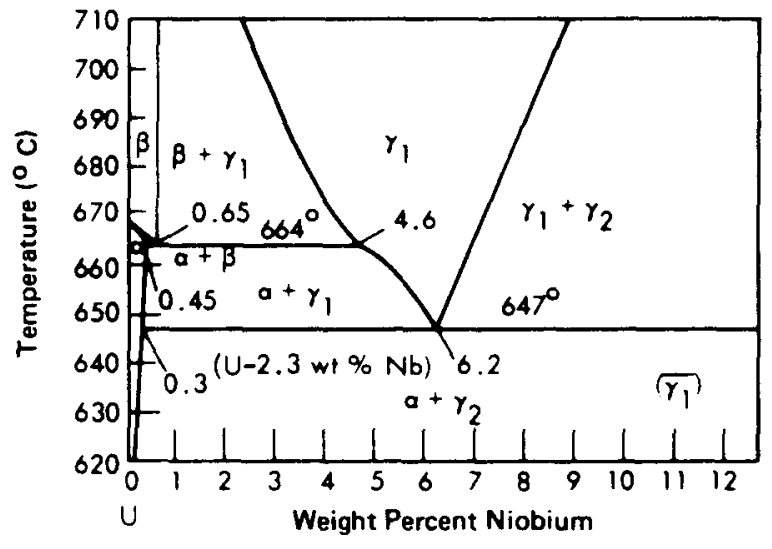

(b) Details of the Uranium-Rich End of the Overall Diagram.

Figure 1. URANIUM-NIOBIUM PHASE DIAGRAM. (From Elliott ${ }^{1}$ ) that of the equilibrium $\gamma_{2}$ phase. When studying the isothermal aging behavior of a 21.2 at $\%(9.5 \mathrm{wt} \%)$ niobium alloy, Djuric 5 concluded that two distinctly different $\gamma$ phases formed-a body-centered cubic phase, $\boldsymbol{\gamma}^{\prime}$, formed at intermediate times together with the equilibrium $\gamma_{2}$. With increasing time at temperature, the $\gamma^{\prime}$ phase slowly disappeared, leaving only the equilibrium $\alpha$ and $\gamma_{2}$ phases.

Previous investigators have measured the effects on mechanical properties of U-Nb alloys resulting from isothermal aging in the $\alpha+\gamma_{2}$ phase field (Table 1). $6-9$ Isothermal aging at $500^{\circ} \mathrm{C}$ for up to eight hours did not produce a ductile material. There were indications from the available data that higher aging temperatures might produce suitable combinations 
of strength and ductility. For instance, the data of Banker 7 and Jackson 8 indicated that a $0.2 \%$ offset yield strength in excess of $540 \mathrm{MPa}$ and an elongation of in excess of $12 \%$ might be attainable. The cooling rate appeared to have been an influencing factor in the difference between the data of Banker and Jackson at $600^{\circ} \mathrm{C}$ (Table 1). Though not shown in the table, Banker also observed a large variability in yield strength.

Table 1

RESULTS OF PREVIOUS STUDIES THAT PERTAIN TO THE EFFECTS OF AGING ON THE MECHANICAL PROPERTIES OF URANIUM-6 NIOBIUM ALLOY

\begin{tabular}{cccccc}
\hline $\begin{array}{c}\text { Temperature } \\
\left({ }^{\circ} \mathrm{C}\right)\end{array}$ & $\begin{array}{c}\text { Time } \\
(\mathrm{hrs})\end{array}$ & $\begin{array}{c}\text { Type } \\
\text { Cooling }\end{array}$ & $\begin{array}{c}\text { Yield Strength } \\
(\mathrm{MPa})\end{array}$ & $\begin{array}{c}\text { Elongation } \\
(\%)\end{array}$ & Reference \\
\hline 500 & 8 & $?$ & 1200 & 4 & Ammons $^{6}$ \\
500 & 2 & $?$ & 1450 & 2 & Ammons $^{6}$ \\
500 & 1 & Air Cool & $\sim 1309$ & $\sim 3$ & Jackson $^{8}$ \\
600 & 1 & Air Cool & $\sim 896$ & $\sim 12$ & Jackson 8 \\
600 & 1 & Water Quench & 540 & 12 & Banker \\
600 & 10 & $?$ & 1100 & 9.8 & Koger 9 \\
\hline
\end{tabular}

(1) At $0.2 \%$ offset.

Based upon the existing data, initial experiments were performed to determine the effect of isothermal aging at $550-600^{\circ} \mathrm{C}$ on the $0.2 \%$ yield strength and elongation of the U-6 Nb alloy. The rates of heating and cooling to and from the aging temperature were examined during the course of the experiment.

\section{EXPERIMENTAL PROCEDURE}

Plate for this study was produced by double arc melting virgin material into a 152-mm-diameter ingot, upset forging from 140 to $50 \mathrm{~mm}$, homogenizing for 10 hours at $1050^{\circ} \mathrm{C}$, hot rolling to $13 \mathrm{~mm}$, vacuum heat treating for one hour at $800^{\circ} \mathrm{C}$, and water quenching. Chemical analysis of the entire face of an ingot revealed a niobium concentration of $5.96 \pm 0.06 \%$. Tensile-specimen blanks $(12.7 \times 12.7 \times 100 \mathrm{~mm})$ were cut from the plate and identified as to their location within the plate. Specimen blanks were then randomly drawn for each heat-treatment condition. Heat treatment was performed by either placing the blanks in a hot furnace and evacuating or loading them into an initially cold furnace, evacuating, and heating to temperature. A vacuum atmosphere of $0.13 \mathrm{MPa}$ was utilized, and the hold time was started when the furnace equilibrated at the aging temperature. Temperature was maintained constant to $\pm 3^{\circ} \mathrm{C}$. Quenching was performed by dropping the blanks into still water, while air cooling was accomplished by dropping the blanks onto asbestos cloth.

Specimens for microstructural and $X$-ray analysis were produced in the same manner as tensile blanks. Optical metallographic specimens were produced by using conventional mounting, polishing, and etching techniques. Both electron metallography and $X$-ray diffraction were performed on the metallographic specimens. Two-stage polyvinyl alcohol replicas were made of each lightly etched specimen, shadowed with a gold-palladium alloy, and examined in the transmission electron microscope. 
$X$-ray diffraction patterns were determined by using monochromatic copper $K \alpha_{1,2}$ radiation from 30 to 110 degrees of two theta $(2 \theta)$. Positions of the twelve strongest $\alpha$-phase peaks were measured and utilized to determine the lattice parameters of the $\alpha$-phase transformation product. The lattice parameters of the $\boldsymbol{\gamma}$-phase product were calculated from the peak position of the $\gamma$-(200) planes, measured using chromium $K \alpha_{1,2}$ radiation. The $\alpha$-uranium lattice-parameter calculations were performed by using a least-squares refinement program. ${ }^{10}$ Relative intensity changes of the $\gamma-110$ and $\alpha-110,021$, and 002 peaks were determined by step scanning from 34 to 39 degrees $2 \theta$, using 0.05 degree $2 \theta$ steps and 40-second counting intervals.

\section{RESULTS}

\section{Mechanical Properties}

Table 2 lists the $0.2 \%$ offset yield strength and elongation values from the heat-treatment conditions evaluated in this experiment. Average-yield-strength values and $95 \%$ confidence intervals for three specimens are given for each heat-treatment condition (the average elongation values are given in parentheses). Graphs of the data contained in the first two

Table 2

YIELD STRENGTH AND ELONGATION FOR AGED URANIUM-6 NIOBIUM ALLOY

\begin{tabular}{|c|c|c|c|c|c|}
\hline \multirow{2}{*}{$\begin{array}{c}\text { Time } \\
\text { at } \\
\text { Temperature } \\
\text { (hrs) }\end{array}$} & \multicolumn{3}{|c|}{ Placed in Furnace at Temperature } & \multicolumn{2}{|c|}{ Heated to Temperature in Cold Furnace } \\
\hline & $\begin{array}{l}600^{\circ} \mathrm{C} \text { then } \\
\text { Air Cooled }\end{array}$ & $\begin{array}{c}600^{\circ} \mathrm{C} \text { then } \\
\text { Water Quenched }\end{array}$ & $\begin{array}{l}550^{\circ} \mathrm{C} \text { then } \\
\text { Air Cooled }\end{array}$ & $\begin{array}{c}600^{\circ} \mathrm{C} \text { then } \\
\text { Water Quenched }\end{array}$ & $\begin{array}{l}550^{\circ} \mathrm{C} \text { then } \\
\text { Water Quenched }\end{array}$ \\
\hline 0.5 & $\begin{array}{r}989 \pm 50^{(1)} \\
(8.2 \pm 1.5)^{(2)}\end{array}$ & $\begin{array}{l}740 \pm 356 \\
(11.7 \pm 5.7)\end{array}$ & $\begin{array}{l}1127 \pm 23 \\
(3.8 \pm 5.0)\end{array}$ & $\begin{array}{c}960 \pm 19 \\
(12.0 \pm 0)\end{array}$ & \\
\hline 1.0 & $\begin{array}{c}807 \pm 132 \\
(12.5 \pm 3.7)\end{array}$ & $\begin{array}{c}799 \pm 279 \\
(11.8 \pm 0.7)\end{array}$ & & & \\
\hline 2.0 & $\begin{array}{c}940 \pm 22 \\
(11.8 \pm 3.2)\end{array}$ & $\begin{array}{c}848 \pm 94 \\
(13.2 \pm 0.7)\end{array}$ & $\begin{array}{l}985 \pm 30 \\
(3.2 \pm 2.6)\end{array}$ & & $\begin{array}{c}913 \pm 3 \\
(13.5 \pm 1.2)\end{array}$ \\
\hline 4.0 & $\begin{array}{r}861 \pm 30 \\
(14 \pm 3.7)\end{array}$ & $\begin{array}{c}801 \pm 53 \\
(15.7 \pm 1.5)\end{array}$ & $\begin{array}{c}887 \pm 43 \\
(4.5 \pm 6.9)\end{array}$ & $\begin{array}{c}794 \pm 61 \\
(12.0 \pm 6.2)\end{array}$ & $\begin{array}{c}843 \pm 19 \\
(17.0 \pm 0)\end{array}$ \\
\hline 5.0 & & & & $\begin{array}{c}766 \pm 21 \\
(14.2 \pm 11.2)\end{array}$ & \\
\hline 6.0 & & & & $\begin{array}{c}754 \pm 17 \\
(16.2 \pm 3.5)\end{array}$ & $\begin{array}{l}788 \pm 90 \\
(18.2 \pm 0.7)\end{array}$ \\
\hline 7.0 & & & & $\begin{array}{c}743 \pm 48 \\
(15.7 \pm 7.9)\end{array}$ & \\
\hline 8.0 & $\begin{aligned} 768 & \pm 45 \\
(17.8 & \pm 2.0)\end{aligned}$ & $\begin{array}{c}738 \pm 32 \\
(18.5 \pm 1.2)\end{array}$ & $\begin{array}{c}845 \pm 22 \\
(16.0 \pm 5.0)\end{array}$ & & $\begin{array}{c}784 \pm 83 \\
(18.5 \pm 1.2)\end{array}$ \\
\hline
\end{tabular}

(1) Yield strength, $0.2 \%$ offset (MPa).

(2) Elongation (\%). 
columns of Table 1 are given in Figure 2. Within experimental error, the average yield strength of the water-quenched material increased and remained reasonably uniform with increased aging time, while the air-cooled material gradually decreased. The variability in yield strength also decreased considerably with increased aging time. Elongation, on the other hand, showed a tendency to increase with the aging time at temperature. With the

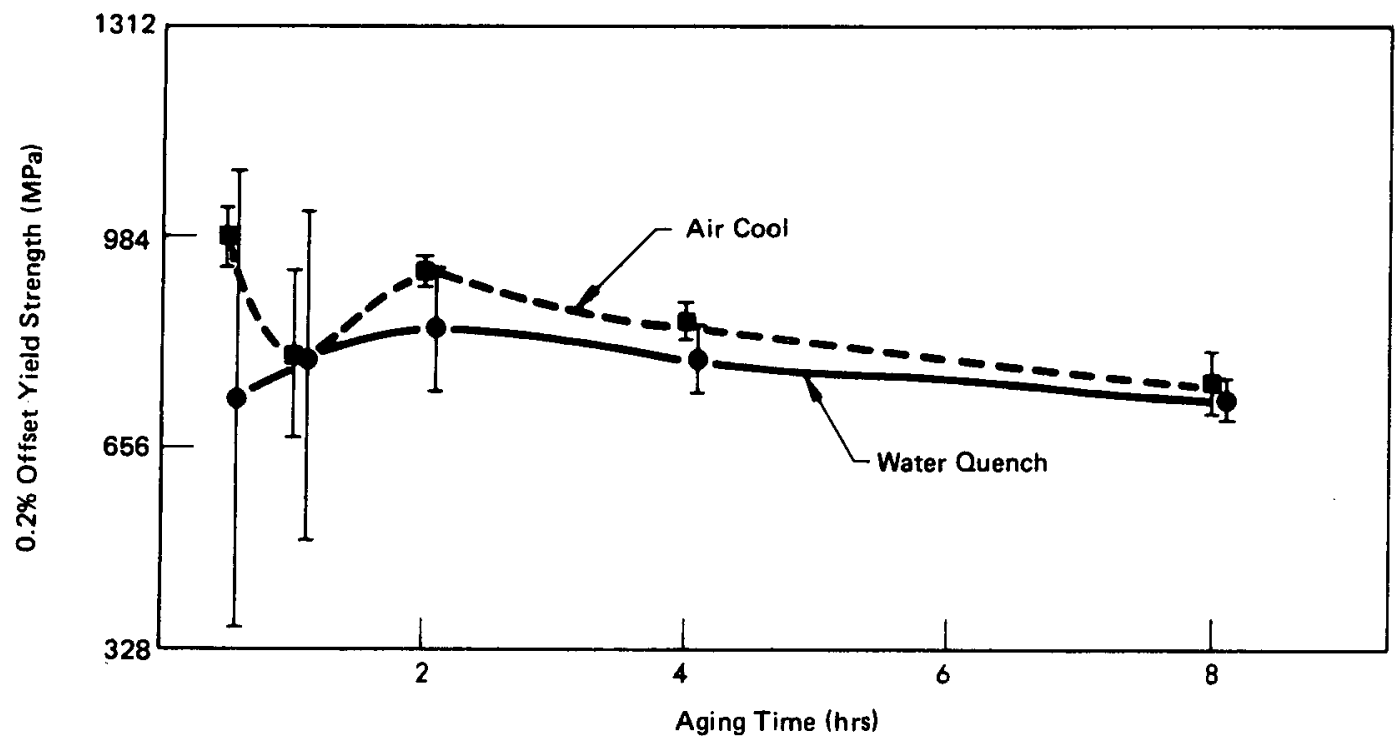

(a) $0.2 \%$ Offset Yiold.

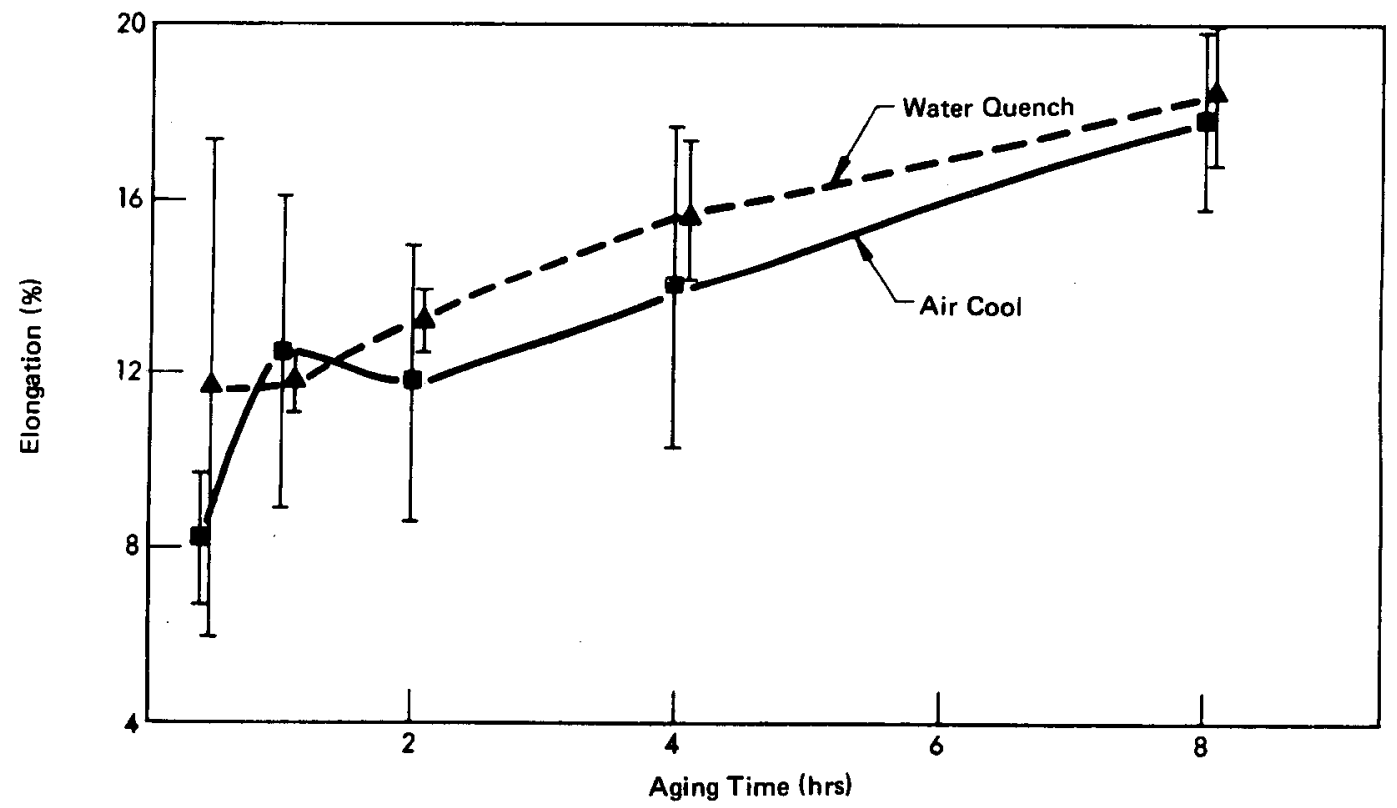

(b) Elongation .

Figure 2. MECHANICAL PROPERTIES OF URANIUM-6 NIOBIUM ALLOY THAT WAS ISOTHERMALLY AGED AT $600^{\circ} \mathrm{C}$, FOLLOWED BY AIR COOLIING OR WATER QUENCHING. (Bars on the Data Points Indicate the 95\% Confidence Interval of the Mean, Based on Three Data Points) 
exception of the 0.5-hour treatment, variability of elongation was lower for the water-quenched material than for the air-cooled specimens.

Isothermal heat treatments were performed at $550^{\circ} \mathrm{C}$ to compare the mechanical-property values obtained to those obtained after the $600^{\circ} \mathrm{C}$ heat treatments. Data after these treatments, together with data after the $600^{\circ} \mathrm{C}$ air-cool treatment, are used to provide the curves of Figure 3. Yield strength was higher for the $550^{\circ} \mathrm{C}$ isothermally aged material, while elongation was reduced greatly from the $600^{\circ} \mathrm{C}$ treatment. Variability of elongation was also quite high for the material aged at $550^{\circ} \mathrm{C}$.

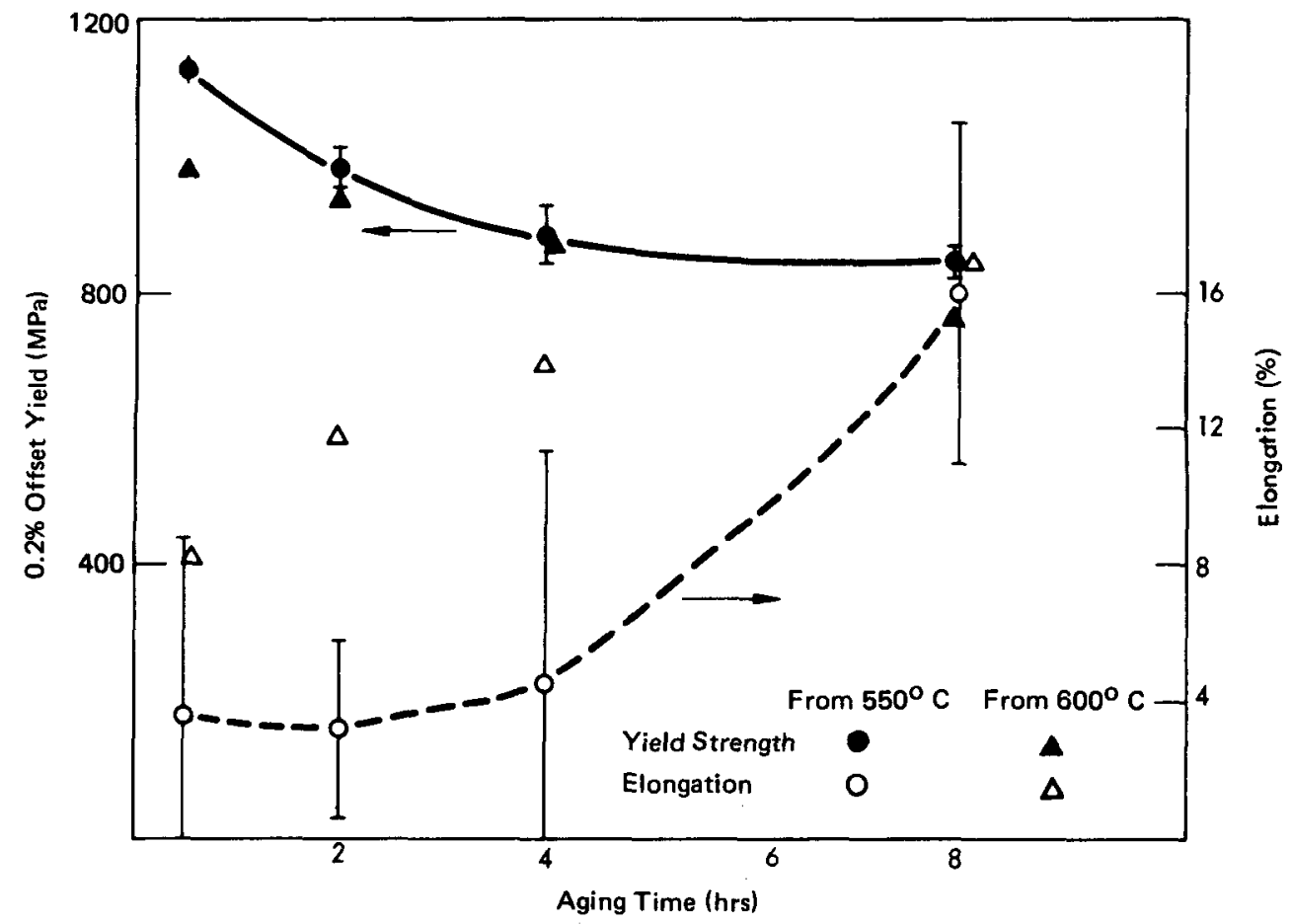

Figure 3. YIELD-STRENGTH (AT 0.2\% OFFSET) AND ELONGATION OF URANIUM-6 NIOBIUM ALLOY THAT WAS ISOTHERMALLY AGED AT $550^{\circ} \mathrm{C}$ AND AIR COOLED. (Average-YieldStrength and Elongation Values for the $600^{\circ} \mathrm{C}$ Heat-Treated and Air-Cooled Specimens are also Indicated)

In considering a heat treatment for use in production, it appeared, based on the $600^{\circ} \mathrm{C}$ data, that air cooling offered no advantages over water quenching. Further, air cooling from such temperatures would be impractical due to the rapid oxidation which would occur. Vacuum/water-quenching heat treatments were then evaluated for their effect on the mechanical properties. Figure 4 gives the results of these heat treatments. The trends in vield strength and elongation were similar to those of the air-cooled specimens. The mechanical properties of specimens aged at $550^{\circ} \mathrm{C}$ exhibited less variability than the properties of specimens aged at $600^{\circ} \mathrm{C}$. A comparison of Figures 3 and 4 showed that a slower heatup from a cold start was equivalent to longer isothermal aging times. For instance, the yield strength developed by a four-hour isothermal anneal was equal to that 


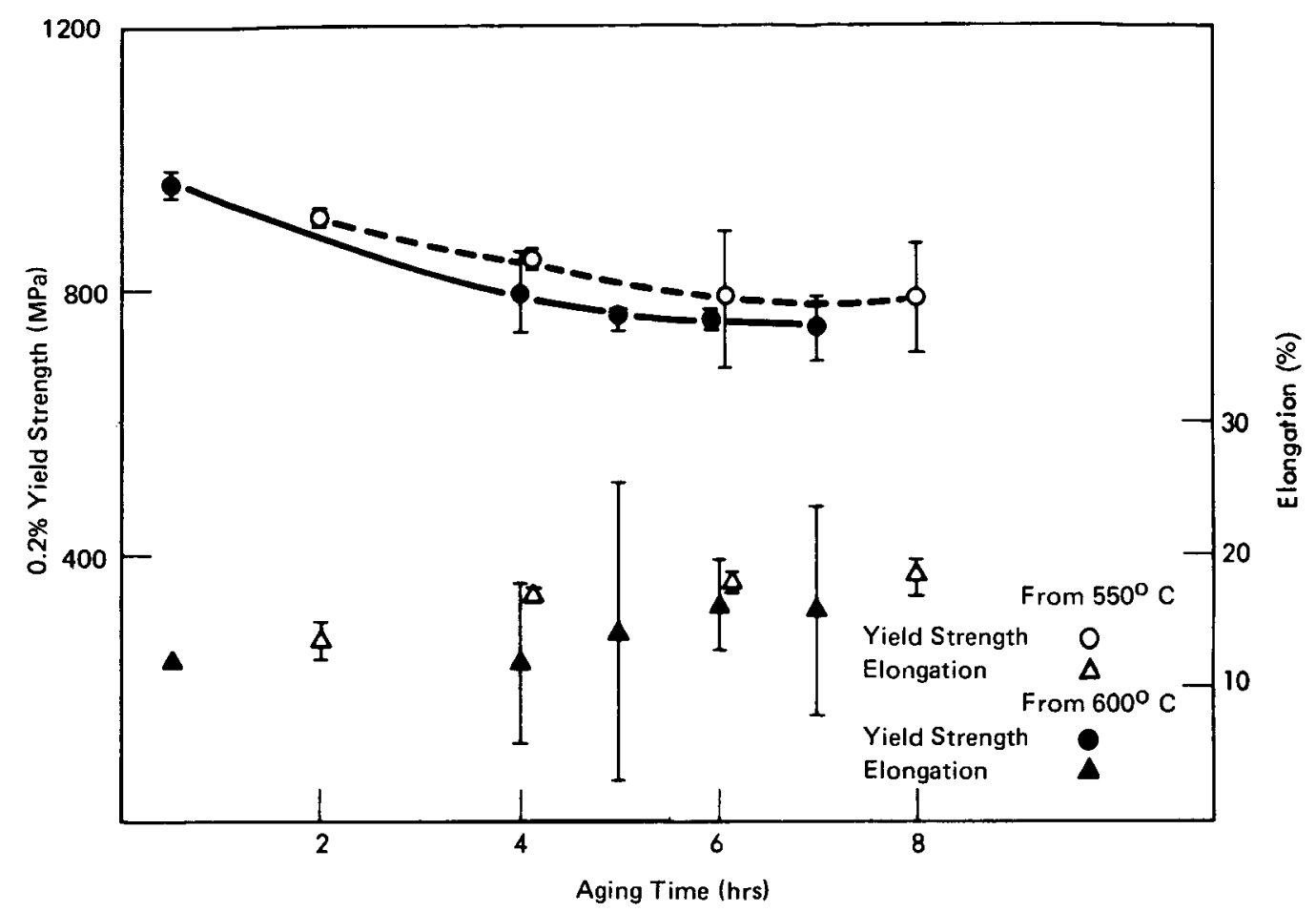

Figure 4. YIELD-STRENGTH (AT $0.2 \%$ OFFSET) AND ELONGATION VALUES OF URANIUM-6 NIOBIUM ALLOY SPECIMENS THAT WERE AGED AT 550 AND $600^{\circ} \mathrm{C}$ IN AN INITIALLY COLD FURNACE AND WATER QUENCHED.

produced by a two-hour anneal from a cold start. Intuitively, it would be expected that the longer thermal exposure during heatup (approximately one hour for the present experiment) would produce additional aging.

\section{Microstructure}

Figure 5 shows the optical microstructure of the U-6 Nb alloy aged for $0.5,2$, and 8 hours at $600^{\circ} \mathrm{C}$. The volume fraction of the lamellar structure growing from inclusions and grain boundaries increased from 0.5 to 2.0 hours, but remained essentially constant from 2.0 to 8.0 hours. Because a bright field illumination would not reveal the structure of specimens aged at $550^{\circ} \mathrm{C}$, microstructures were photographed by using polarized light, as seen in View d, Figure 5. The untransformed material was the solid black areas in View d. A comparison with $V$ iew a revealed that the transformation was much more rapid at $550^{\circ} \mathrm{C}$. Within one hour at $550^{\circ} \mathrm{C}$, the alloy had transformed completely. Figure 6 is a higher-magnification micrograph of a specimen aged for 24 hours at $600^{\circ} \mathrm{C}$. The original pearlite was believed to be the dark band around the grain boundaries and did not appear to have increased in volume from 2.0 to 24 hours.

Electron micrographs of specimens aged at $600^{\circ} \mathrm{C}$ revealed many different types of fine structure that were not resolvable in the optical microscope. Many of the structures common to all specimens were independent of the cooling rate and, for the most part, were independent of the aging time. Figure 7 shows the most commonly observed 

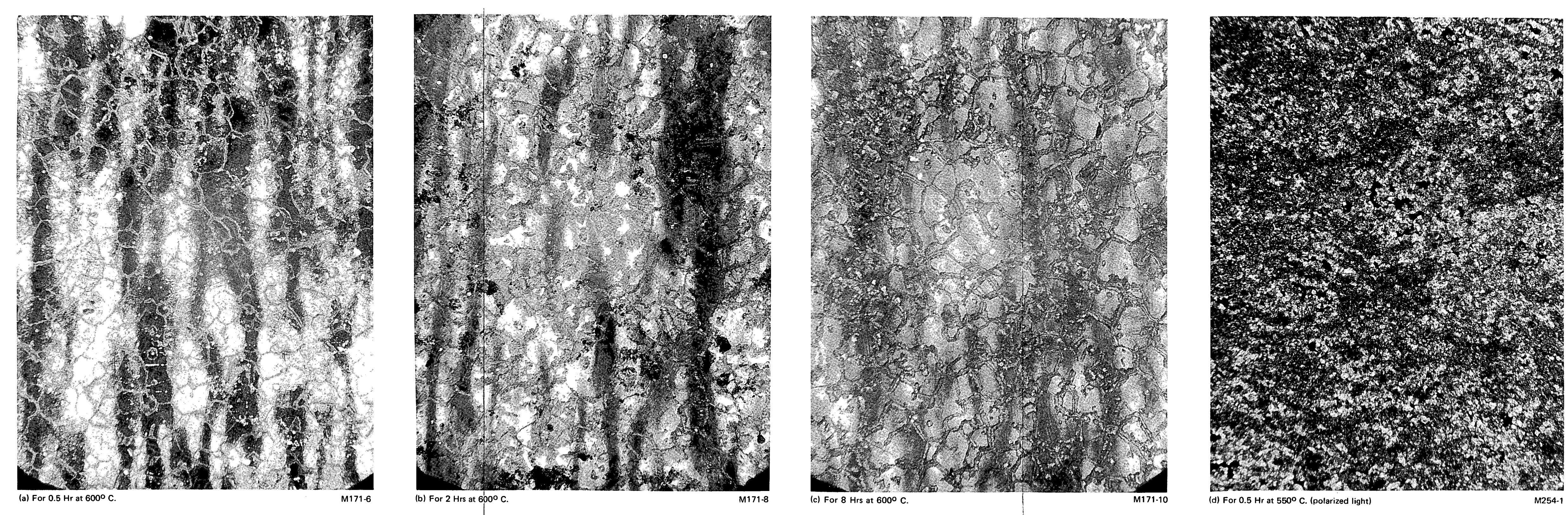
Figure 5. OPTICAL Microstructures OF URANIUM.6 NIOBIUM ALLOY THAT WAS AGED FOR 0.5, 2, AND 8 HOURS AT 6000 C, AND FOR 0.5 HOUR AT 5500 C. (Bright Field IIlumination; 100X) 


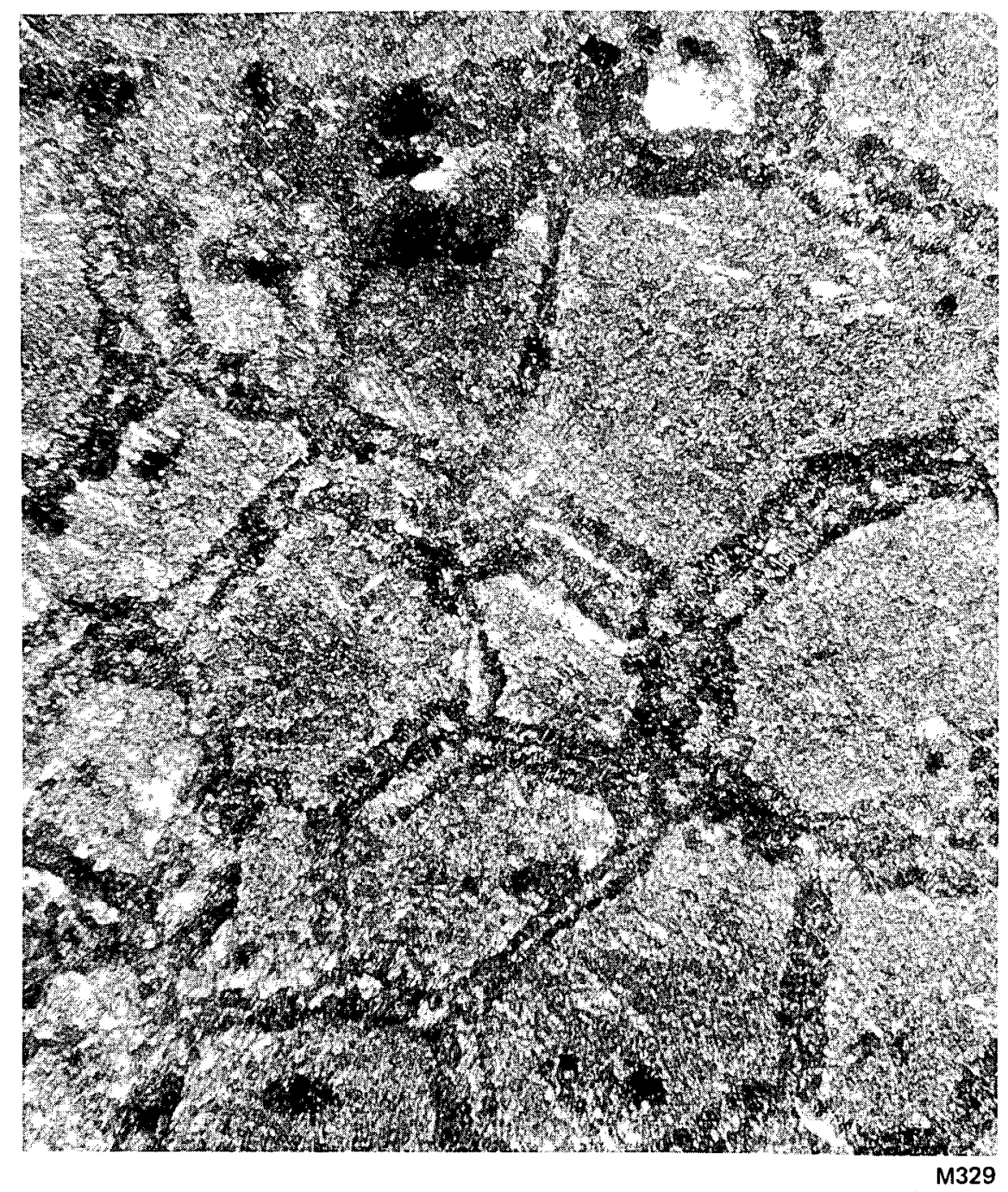

Figure 6. MICROSTRUCTURE OF A URANIUM-6 NIOBIUM SPECIMEN THAT WAS AGED FOR 24 HOURS AT $600^{\circ} \mathrm{C}$. (Bright Field Illumination; 400X)

microstructures for the $600^{\circ} \mathrm{C}$-aged specimens. A typical lamellar structure that was characteristic of monotectoidally decomposing systems is seen in View a. The interlamellar spacing of the structure varied considerably within a specimen, as noted in View b. Points $B$ and $C$ show a very fine spacing, while the area noted as Point $A$ has a very large spacing. ${ }^{11}$ In some areas, such as View $c$, it appeared that the fine pearlitic structure might have spherodized. An entirely different structure (View d), resembling a Widmanstatten structure, was observed and was frequently seen adjacent to the pearlitic areas, as in View e. A third type of structure, shown in View $f$, appeared to be intermediate between the pearlitic and Widmanstatten structures. In many areas (such as Points $A$ and $B$ ) there were fairly large crystallographic plates; but, in other regions, the plates were too short to ascertain any crystallographic relationship.

Replicas of specimens aged at $550^{\circ} \mathrm{C}$ revealed basically two types of structure (Figure 8). View a shows very fine lamellar regions which are growing to encompass untransformed 


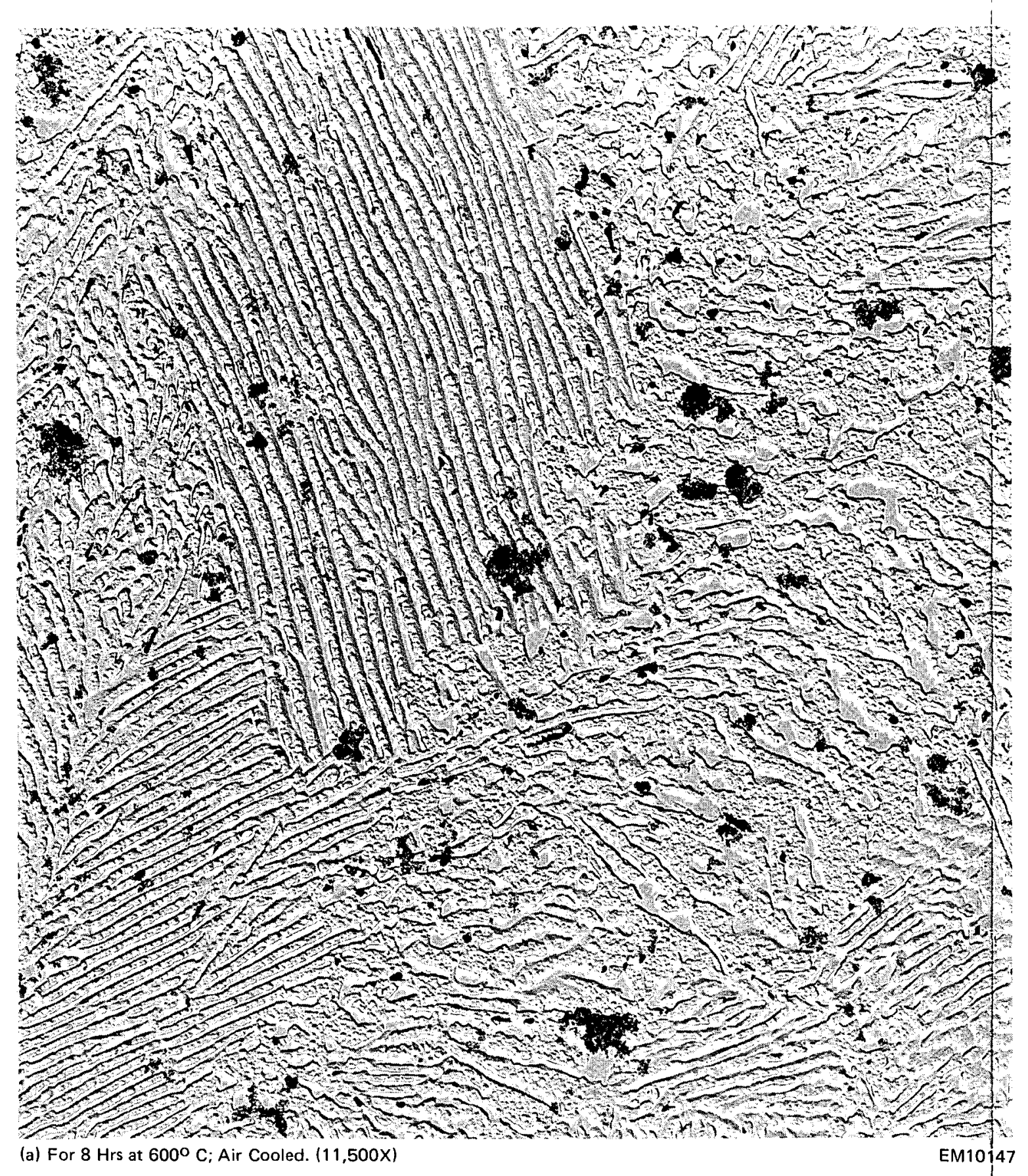

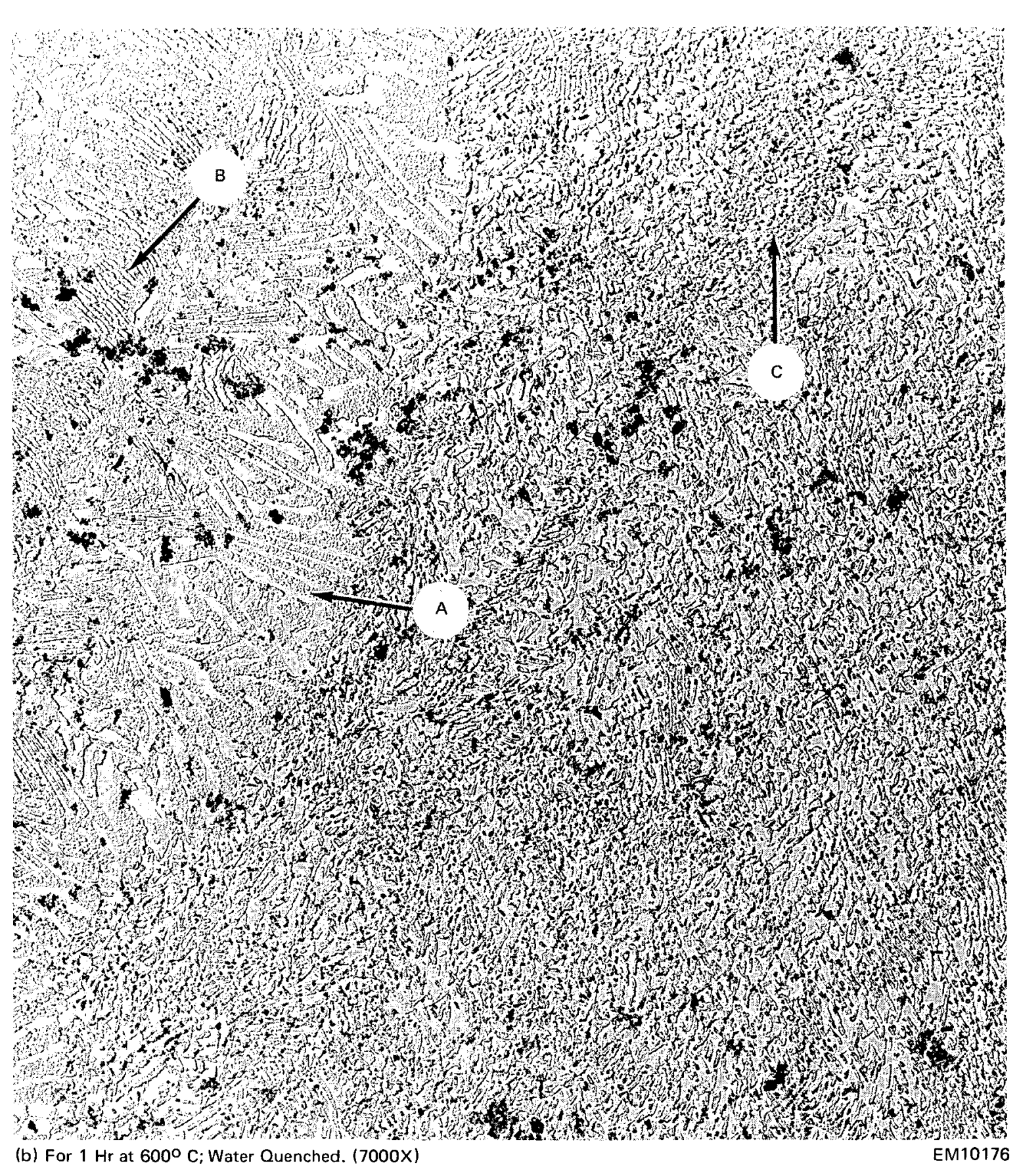

Figure 7. REPRESENTATIVE MICROSTRUCTURES OF SPECIMENS THAT WERE AGED AT $600^{\circ} \mathrm{C}$

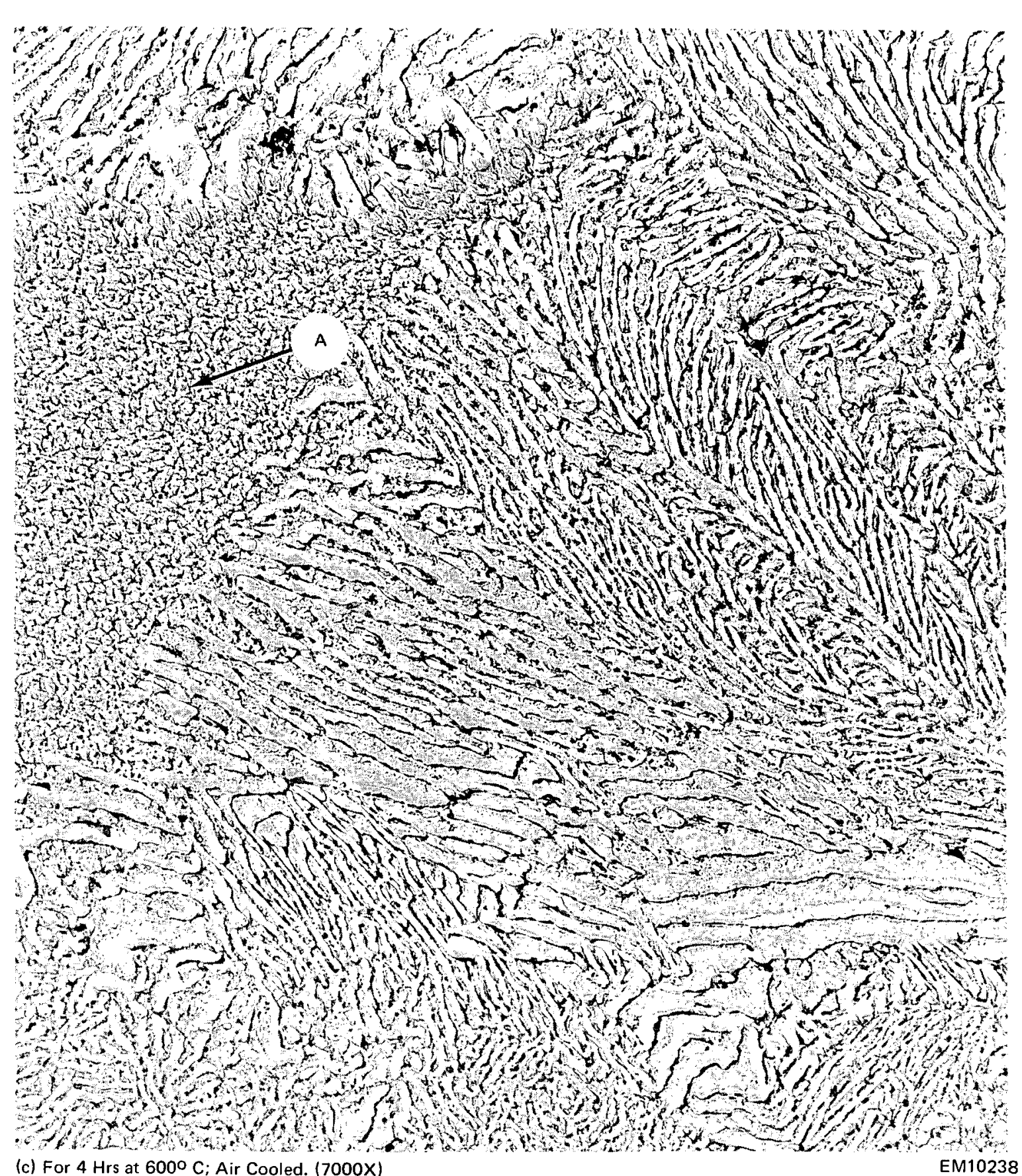



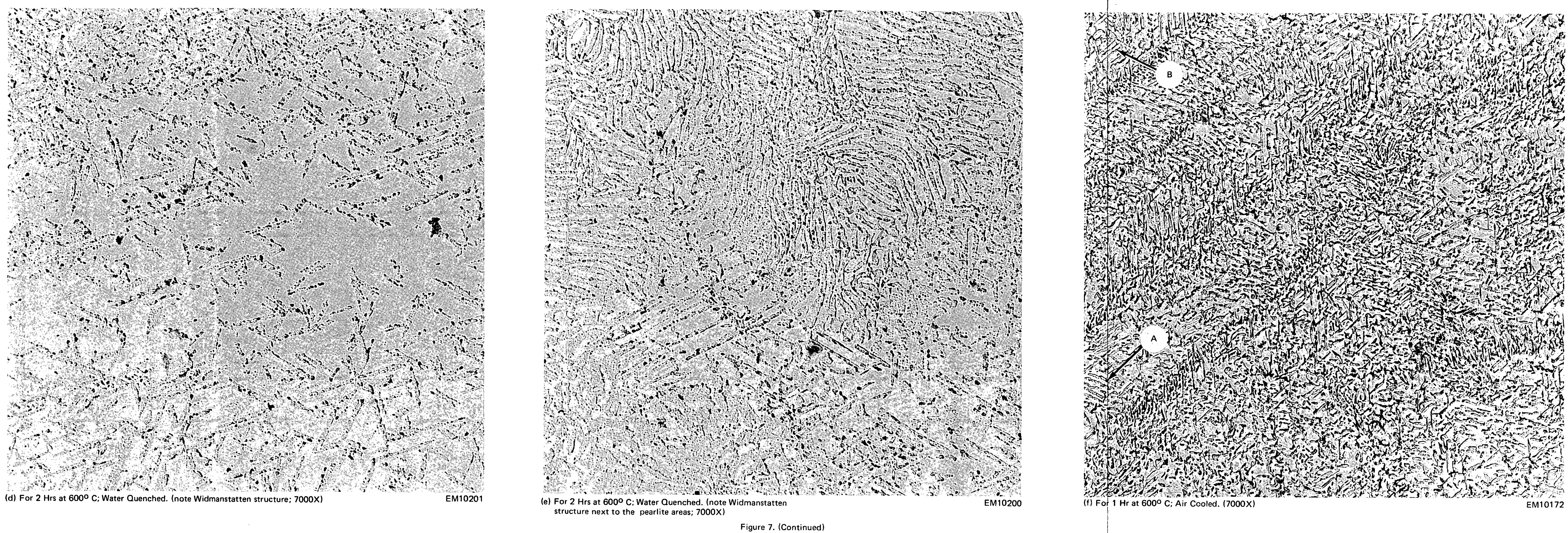

1 

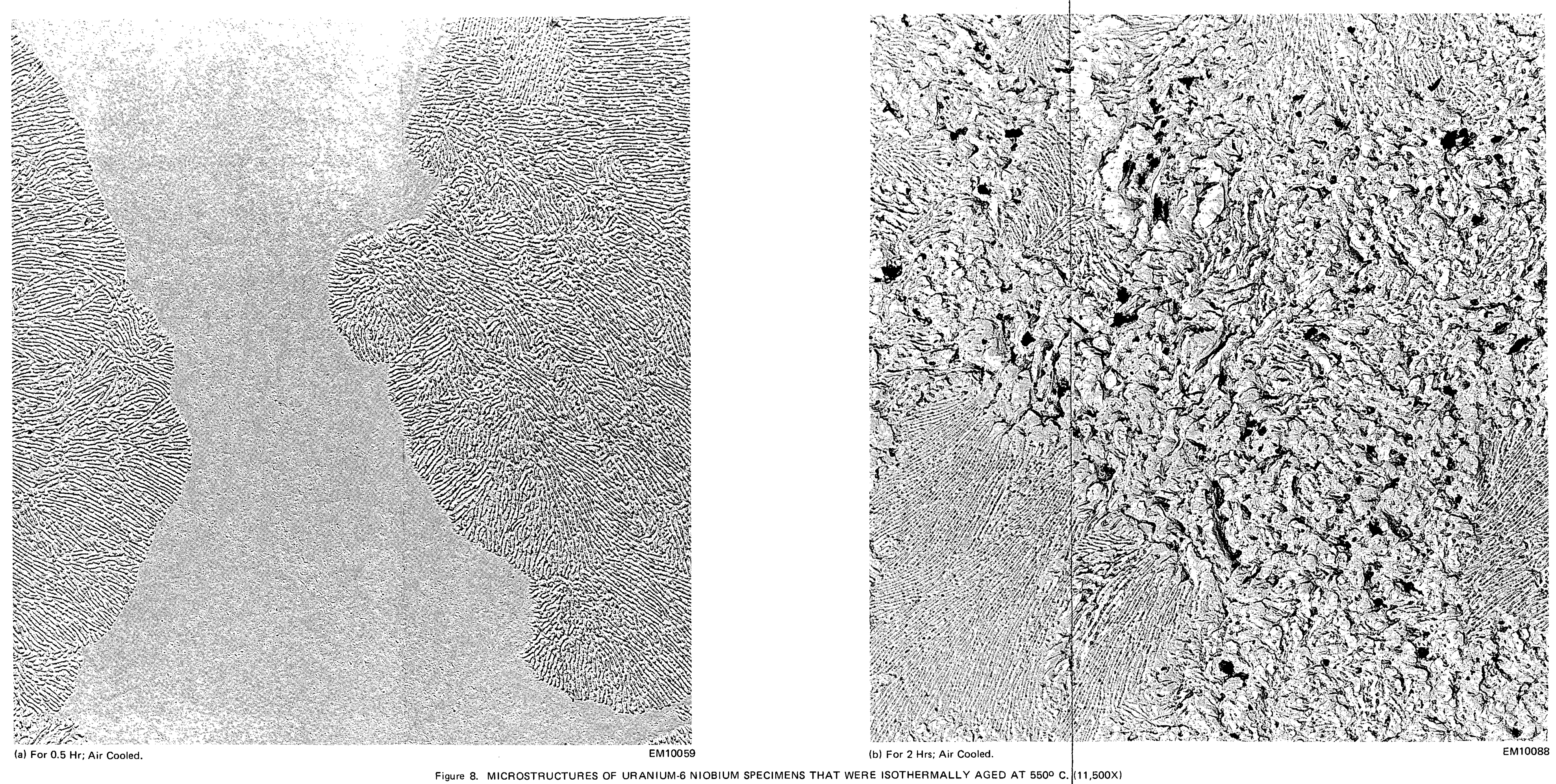
material. A second type of structure (View b) consisted of the fine pearlite surrounded by regions containing what appeared to be spheroidizing pearlite.

\section{X-Ray Diffraction}

Figure 9 presents diffractometer scans of the specimens corresponding to those of the second column of Table 2, while Figure 10 gives scans of similar data from specimens corresponding to those of the third column. After 0.5 and 1.0 hour, a small amount of the $\alpha^{\prime \prime}$ phase was detectable in the $600^{\circ} \mathrm{C}$-aged specimens. No distinct $\gamma^{\prime}$ phase was detected. However, after 24 hours at $600^{\circ} \mathrm{C}$, the $\boldsymbol{\gamma}$-phase peak appeared to be splitting. A decrease in the $\gamma$-phase lattice parameter (indicated by a peak shift tohigher $2 \theta$ ) occured with increasing time. At $550^{\circ} \mathrm{C}$, the transformation proceeded more rapidly than at $600^{\circ} \mathrm{C}$. There was no difference in the $\alpha$-phase lattice parameters as a function of either time at temperature, temperature, or method of cooling. Additionally, the lattice parameters of the $\alpha$ phase corresponded closely to those of pure uranium. At short aging times, the. $\boldsymbol{\gamma}$-phase peaks were broad and generally overlapped the $\alpha$-phase peaks, which led to a large imprecision in determination of the $\boldsymbol{\gamma}$-phase lattice parameters.

\section{Discussion of Results}

Much of the variability in the results of this experiment can be explained on the basis of chemical inhomogeneity. The banded microstructure of Figure 5 was due to chemical inhomogeneities, as have been discussed in more detail elsewhere. ${ }^{12} \mathrm{~A}$ more subtle effect was that of gross chemical variation. A graph of chemical variation within an arc-melted ingot is presented in Figure 11 and is from the work of Banker. 13 If an ingot is upset and round rolled into a plate, the center-to-edge chemical variation of the ingot is maintained within the plate. An example will be given of how both short and long-range chemical inhomogeneity can affect properties.

The largest variability in yield strength (Table 2) occurred for the group of specimens receiving the 0.5 -hour aging at $600^{\circ} \mathrm{C}$, followed by water quenching. The large variability of this group of three specimens was a result of one specimen having had a yield strength of $575 \mathrm{MPa}$ while the remaining two specimens had yield strengths of $821 \mathrm{MPa}$. Metallographic mounts were made of the longitudinal cross sections of both a high and low-yield-strength specimen (Figure 12). A larger fraction of the higher-yield-strength specimen has a dark appearance. A higher-magnification micrograph, View c, shows that the dark appearance was due to increased nucleation of pearlite from grain boundaries and inclusions. In addition, the darker regions of microstructure contain a more general precipitation which appeared to be a decoration of the original $\alpha^{\prime \prime}$ platelets within the bulk of a grain.

In order to elucidate the reasons for the observed variation in microstructure, electron microprobe measurements of niobium were made on the light and dark regions of Figure 12 , View b. A 20 by $20 \mu \mathrm{m}$ raster of the beam was used for each location in order to avoid counting a single niobium-rich particle. Ten each of the light and dark areas were analyzed by using this technique. The dark areas were found to contain $6.75 \pm 0.83 \mathrm{wt} \%$ 


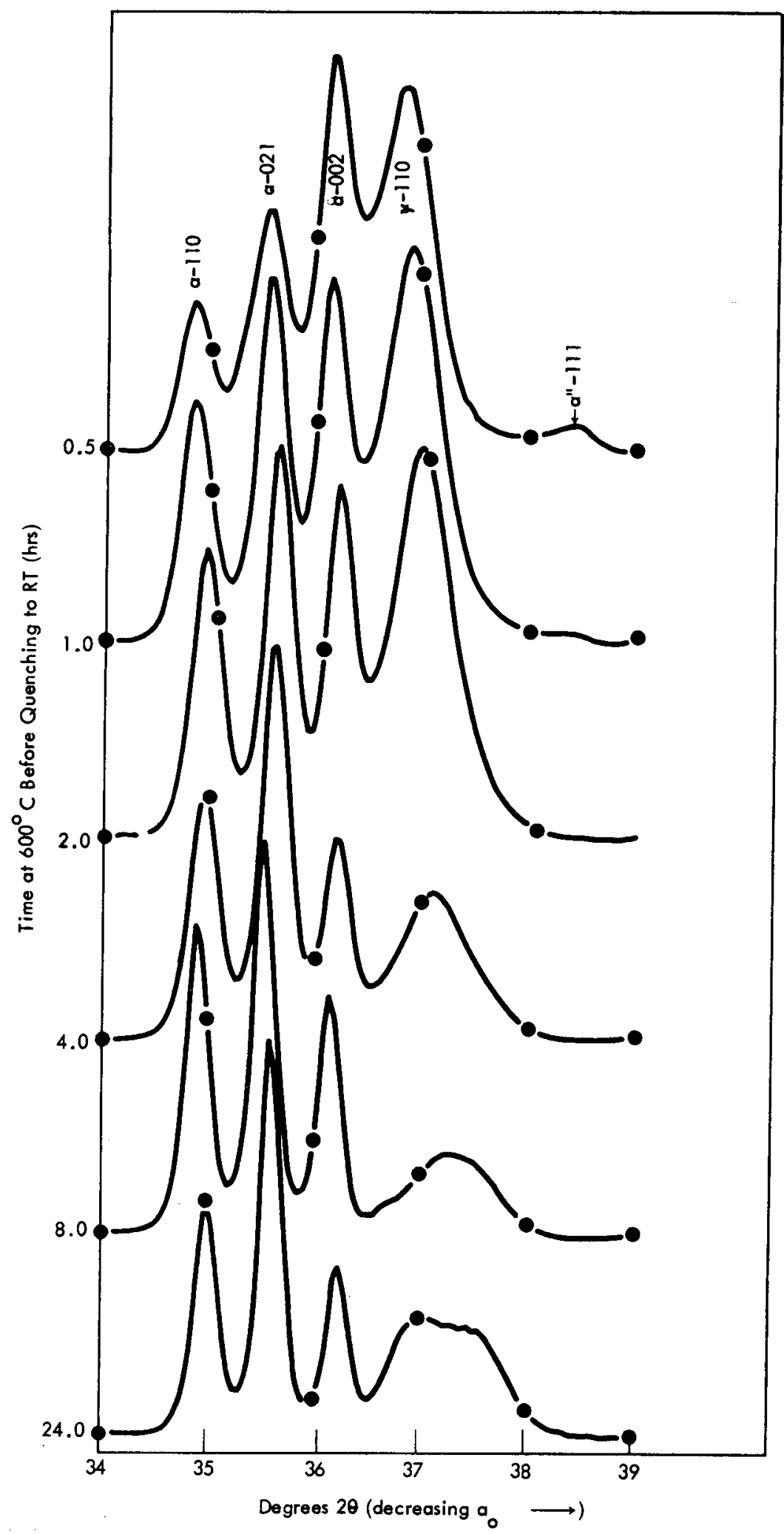

Figure 9. DIFFRACTOMETER TRACES OF URANIUM-6 NIOBIUM SPECiMENS THAT WERE ISOTHERMALLY TRANSFORMED AT $600^{\circ} \mathrm{C}$, FOLLOWED BY WATER QUENCHING TO ROOM TEMPERATURE. 


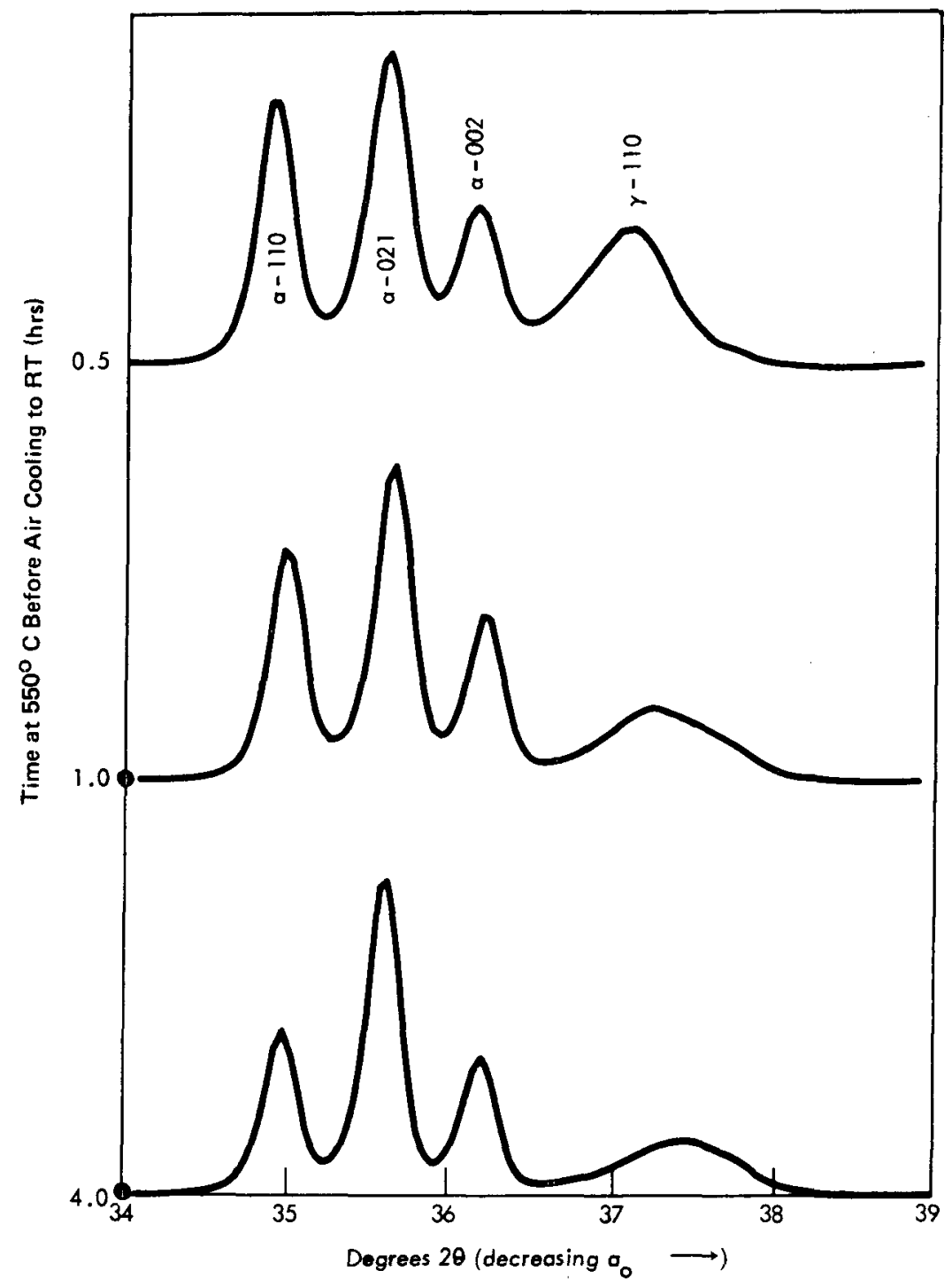

Figure 10. DIFFRACTOMETER TRACES OF URANIUM-6 NIOBIUM SPECIMENS THAT WERE ISOTHERMALLY TRANSFORMED AT $550^{\circ} \mathrm{C}$, FOLLOWED BY AIR COOLING TO ROOM TEMPERATURE.

niobium, while the light areas contained $5.63 \pm 0.39 \mathrm{wt} \%$ niobium. Wet chemical analysis to determine the bulk niobium content was performed on the two specimen gage lengths of Figure 12; and, within experimental error, the specimens contained the same amount of niobium. Thus, the difference in mechanical behavior apparently was due to banding or macrosegregation. Banding has been shown to be more severe (ie, more widely spaced bands and greater segregation) in the ingot/plate center than in the ingot/plate edge. A check on the original location of the two specimens showed that the specimen of View a (Figure 12) came from the plate edge, while the specimen of View b came from near the plate center.

It is apparent from the previous observations that the kinetics of the decomposition of U-6 $\mathrm{Nb}$ are highly dependent upon the niobium concentration. There has been no analysis of the effects of niobium concentrations near the monotectoid composition on the decomposition 


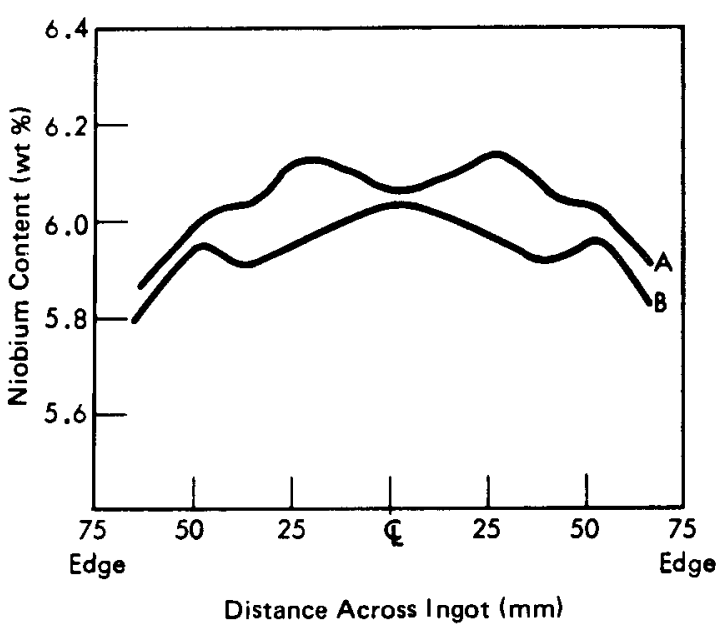

Figure 11. GRAPH OF CENTER-TO-EDGE NIOBIUM SEGREGATION IN A $152-\mathrm{mm}$-DIAMETER URANIUM-6 NIOBIUM ARC-MELTED INGOT. kinetics of well-homogenized specimens. Though slight differences in niobium concentration apparently caused significant differences in the reaction rate, the overall effect on mechanical properties eventually was minimized by aging for long times. Thus, the variability of yield strength, which is indicated by the bars in Figure 2, decreased with increased time at $600^{\circ} \mathrm{C}$.

Both aging time and aging temperature affected the yield strength of U-6 Nb. Figure 4 shows that aging at either 550 or $600^{\circ} \mathrm{C}$ resulted in a decrease in yield strength with time. Yet the yield strength after aging at $500^{\circ} \mathrm{C}$ was consistently higher than that at $600^{\circ} \mathrm{C}$. Marder and Bramfitt ${ }^{14}$ have

shown, for eutectoid steels, that the strength of pearlite is inversely dependent on interlamellar spacing and independent from both the austenite grain size and pearlite nodule diameter. It would seem that an explanation of the difference in yield strength between the 550 and $600^{\circ} \mathrm{C}$-aged material could be based on the observed differences in interlamellar spacing between the two (compare Figure 7, Viewa, and Figure 8, View a ). However, the strength-controlling factor in $600^{\circ} \mathrm{C}$-aged material appears to be more complicated. As seen in Figure 5, Views $\mathrm{c}$ and $\mathrm{d}$, the alloy appears to have never fully transformed to the pearlitic structure, yet the diffraction patterns show only $\alpha$ and $\gamma$ phases present. Some other phase transformation appears to have occurred within the bulk of the grain, giving rise to the "etching" effect of Figure 12, View c. A high-magnification photograph of this same structure is believed to be represented by Figure 7, View $\mathrm{d}$. Though the microstructural and $X$-ray results are not conclusive, it appears that this could be coherent precipitation of $\alpha$ uranium, which has been observed at lower temperatures. 4

In addition to the effects of aging time and temperature on mechanical properties, there was the previously mentioned influence of the heating rate. Heating from an initially ambient temperature at a slow rate produced additional aging, which effectively shifted the time axis relative to isothermal or salt-bath aging. This influence should be kept in mind when utilizing these high-temperature aging treatments. The heating-rate effect may be responsible for some of the variability noted in Table 1 among the different researchers.

\section{CONCLUSIONS}

The following conclusions have been reached as a result of this study:

1. High-temperature aging $\left(550-600^{\circ} \mathrm{C}\right)$ resulted in a very useful combination of mechanical properties-a $0.2 \%$ offset yield strength in excess of $730 \mathrm{MPa}$ and an elongation of $15-18 \%$. 

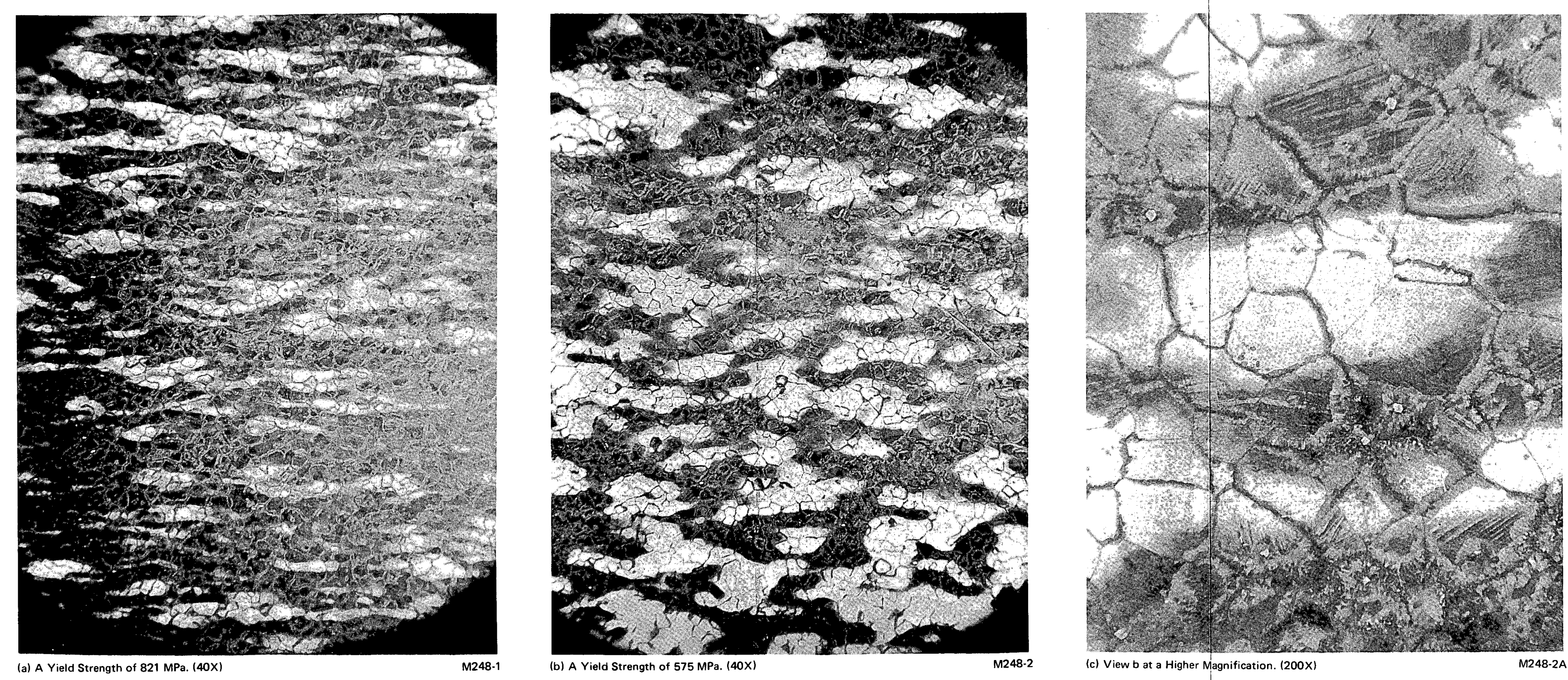

Figure 12. OPTICAL MICROSTRUCTURES OF TWO URANIUM-6 NIOBIUM ALLOY SPECIMENS THAT DEMONSTRATED DIFFERENT YIELD STRENGTHS. 
2. A high degree of variability in mechanical properties was due to both micro and macrochemical segregation. Increased aging time at temperature minimized these effects, while, at the same time, causing some reduction in strength.

3. The heating rate affected the mechanical properties. In terms of strength, slow heating was equivalent to requiring an additional isothermal aging time.

4. Different microstructural features were felt to influence strength in different aging-temperature regimens. 


\section{ACKNOWLEDGEMENTS}

The author wishes to express his appreciation to $D$. $H$. Johnson of the $Y-12$ Development Division for making the $X$-ray diffractometer measurements on the aged specimens. Thanks are also expressed to J. F. McLaughlin for making the transmission electron microscope replicas. 


\section{REFERENCES}

1. Elliott, R. P.; Constitution of Binary Alloys, First Supplement, p 275; McGraw-Hill Book Company, New York (1965).

2. Lehmann, J. and Hills, R. F.; J Nucl Mater, 2, pp 218 - 225 (1961).

3. Jackson, R. J.; Reversible Martensitic Transformations Between Transition Phases of Uranium-Base Niobium Alloys, RFP-1535; Dow Chemical Company-Rocky Flats Division (1970).

4. Jackson, R. J.; Isothermal Transformations of Uranium-13 Atomic Percent Niobium, RFP-1609; Dow Chemical Company-Rocky Flats Division (1971).

5. Djuric, B.; J of Nucl Mater, 44, pp 207 - 214 (1972).

6. Ammons, A. M.; Unpublished Research.

7. Banker, J. G.; Unpublished Research.

8. Jackson, R. J. and Boland, J. F.; Mechanical Properties of Uranium-Base Niobium Alloys, RFP-1703; Dow Chemical Company-Rocky Flats Division (1971).

9. Koger, J. W., et al; Effect of Aging on the General Corrosion and Stress Corrosion Cracking of Uranium-6 wt \% Niobium Alloy, Y-1999; Union Carbide CorporationNuclear Division, Oak Ridge Y-12 Plant, Oak Ridge, Tennessee; November 26, 1975.

10. Williams, D. E.; LCR-2, A Fortran Lattice Parameter Refinement Program, Ames Laboratory Research and Development Report IS-1052; November 1964.

11. Cahn, J. W. and Hagel, W. C.; Acta Met, 11, pp 561 - 574 (1963).

12. Snyder, W. B.; Homogenization of Arc-Melted Uranium-6 Weight Percent Niobium Alloy Ingots, Y-2102; Union Carbide Corporation-Nuclear Division, Oak Ridge Y-12 Plant, Oak Ridge, Tennessee; January 31, 1978.

13. Banker, J. G.; Unpublished Research.

14. Marder, A. R. and Bramfitt, B. L.; Met Trans, 7A pp $365-372$ (1976). 


\section{Distribution}

Aerospace Corporation-ARPA

Kendall, G.

Air Force Armaments Laboratory

Wilson, L.

Air Force Materials Laboratory

Inouye, S.

Battelle Memorial Institute

Meyer, G.

Department of Energy - Oak Ridge

Hickman, H. D.

Leed, R. E.

Zachry, D. S., Jr

Lawrence Livermore Laboratory

Fulton, F. J.

Nelson, W. E:

Woods, D. H.

Los Alamos Scientific Laboratory

Hockett, J. E:

Hoyt, H. C.

Kirby, R. S.

Sandstrom, D.

Oak Ridge Gaseous Diffusion Plant

Stief, S. S.

Wilcox, W. J., Jr

\section{Oak Ridge National Laboratory}

Heestand, R. L.

Inouve, $\mathrm{H}$.

McHargue, C. J.

Ogle, J. C:

Vandermeer, R. A.

Weir, J. R., Jr

Oak Ridge Y-12 Plant

Anderson, R. C.

Beck, D. E.

Bernander, N. K.

Burditt, R. B.

Carpenter, D. A.

Cuddy, L. M.
Dodson, W. H./Googin, J. M.

Duggan, H. G.

Evans, P. A.

Ferguson, J. E.

Fraser, R.J.

Gritzner, V. B.

Haeusler, K. R.

Jackson, V.C.

Jessen, N. C., Jr

Johnson, D. H.

Jones, F. W.

Kahl, K. G.

Keith, A.

Kite, H. T.

Koger, J.W.

Kollie, T.G.

Mason, D. L.

McElroy, B. D.

Mills, J. M., Jr

Myhre, T. C.

Northcutt, W. G., Jr

Phillips, L. R.

Smith, H. F., Jr

Smith, R. D.

Snyder, W. B., Jr (10)

Stoner, H. H.

Tewes, W. E.

Thompson, J. E.

Townsend, A. B.

Walker, L. R.

White, J. C.

Yaggi, W. J.

$Y-12$ Central Files (master copy)

$Y-12$ Central Files (route copy)

$Y-12$ Central Files $(Y-12 R C)$

$Y-12$ Central Files (5)

Paducah Gaseous Diffusion Plant

Bewley, H. D.

Rockwell International - Rocky Flats

Jackson, R. J.

Mataya, $M$.

Sandia - Albuquerque

Eckelmeyer, K. H.

Magnani, N. J.

Rohde, R.W. 
Sandia - Livermore

Adolphson, D. R.

Mote, M. W.

Union Carbide Corporation - New York

Tinsley, S. W.

US Army Armament Research and Development Command

Bloore, E.W.

US Army Ballistics Research Laboratories

Gillich, W.

US Army Materials and Mechanics Research Center

Greenspan, J.

Larson, $F$.

US Naval Weapons Laboratory

Crowe, $R$.

In addition, this report is distributed in accordance with the Category UC-25, Materials, as given in the USERDA Standard Distribution Lists for Unclassified Scientific and Technical Reports, TID-4500. 